\title{
IMPLEMENTASI PEMERINTAHAN YANG BERSIH DALAM KERANGKA RENCANA AKSI DAERAH PEMBERANTASAN KORUPSI (RAD-PK) (Studi Di Kabupaten Pemalang) ${ }^{1}$
}

\author{
Muhammad Fauzan, Bahtaruddin dan Hikmah Nuraini \\ Fakultas Hukum dan Fakultas IImu Sosial dan IImu Politik \\ Universitas J enderal Soedirman Purwokerto \\ E-mail : fauzanhtn@yahoo.co.id
}

\begin{abstract}
This research related to the implementation of good governance, free from corruption, collusion and nepotism. The approach used in this research is a descriptive qualitative approach. The Location of research conducted in the District of Pemalang. Based on the research results can presented that the District of Pemalang is committed and fully supports the government policy in eradicating corruption. District of Pemalang support to efforts to more information accelerate the eradication of corruption stated in the the Regional Action Plan to Accelerate the Eradication of Corruption (RAD-PK) in 2011 -2016 which refers to the Medium Term Development Plan (RPJ M) District of Pemalang from 2011 to 2016 and the National Action Plan for Eradication of Corruption (RAN-PK) and the President of Republic of Indonesia Instruction No. 5 Year 2004 on Accelerating the eradication of corruption. RAD-PK 2011-2016 District of Pemalang is a document that contains an action program that aims to accelerate the eradication of corruption. RAD-PK as a program of action containing concrete measures that have been agreed by the stakeholders in the area, so it has been a commitment of local governments prevention efforts corruption through the development of programs and activities aimed at improving public services and the application of the principles of good governance.
\end{abstract}

Keywords: governance, eradication, corruption

\begin{abstract}
Abstrak
Penelitian ini berkaitan dengan pelaksanaan pemerintahan yang bersih, yang jauh dari korupi, kolusi, dan nepotisme. Metode yang digunakan dalam penelitian ini adalah metode diskriptif dengan pendekatan kualitatif. Lokasi penelitian dilaksanakan di Kabupaten Pemalang. Berdasarkan hasil penelitian dapat dikemukakan bahwa Kabupaten Pemalang berkomitmen dan mendukung penuh terhadap kebijakan pemerintah dalam upaya pemberantasan korupsi. Dukungan Kabupaten Pemalang terhadap upaya percepatan pemberantasan korupsi lebih lanjut dituangkan dalam Rencana Aksi Daerah Percepatan Pemberantasan Korupsi (RAD-PK) Tahun 2011 -2016 yang mengacu pada Rencana Pembangunan J angka Menengah (RPJ M) Daerah Kabupaten Pemalang 2011 - 2016 dan Rencana Aksi Nasional Pemberantasan Korupsi (RAN- PK) serta Instruksi Presiden Republik Indonesia No. 5 Tahun 2004 tentang Percepatan Pemberantasan Korupsi. RAD - PK 2011 - 2016 Kabupaten Pemalang merupakan sebuah dokumen yang memuat program aksi yang bertujuan untuk mempercepat pemberantasan korupsi. RAD-PK sebagai suatu program aksi memuat langkah-langkah konkrit yang telah disepakati para pemangku kepentingan di daerah, sehingga telah menjadi komitmen pemerintah daerah dalam melakukan upaya pencegahan terjadinya korupsi melalui pengembangan program dan kegiatan yang bertujuan untuk perbaikan pelayanan publik serta penerapan prinsipprinsip tata kepemerintahan yang baik.
\end{abstract}

Kata kunci : pemerintahan, pemberantasan korupsi

Tulisan ini merupakan artikel dari hasil penelitian yang dilaksanakan berdasarkan SK Rektor Unsoed No. Kep. 307/ UN23/ PN. 01.00/2012 Tanggal 22 Maret 2012 tentang Pelaksanaan Jasa Penelitian Kerjasama Konsorsium PT. Kogas Driyap Konsultas, PT. IDI Kajang Consultants dan LPPM Unsoed Dalam Kegiatan Proyek SCBD ADB Loan 1964-INO Packade C.2 Implementation of Capacity Building Action Plan Pemalang Districk Central J ava Province. 


\section{Pendahuluan}

Tindak pidana korupsi diyakini merupakan ancaman serius yang akibatnya tidak saja menyerang sendi-sendi perekonomian nasional suatu negara, tetapi juga dapat mempengaruhi sistem perekonomian internasional serta melemahkan nilai-nilai keadilan di semua negara. Berdasarkan kenyataan tersebut, pemberantasan dan sekaligus pencegahan terjadinya tindak pidana korupsi bukan hanya merupakan tanggung jawab satu negara saja, namun membutuhkan kerjasama antar negara/ internasional, termasuk di dalamnya tanggung jawab seluruh elemen masyarakat bangsa tanpa melihat status sosial dan latar belakangnya.

Bangsa-bangsa di duniapun akhirnya menyadari tingkat parahnya korupsi di negaranegara yang ada di dunia sehingga pada akhirnya lahirlah United Nations Convention Against Corruption yang menandai babak baru dalam perlawanan masyarakat dunia terhadap korupsi. Pemberantasan tindak pidana korupsi harus dilakukan secara luar biasa harus diakui merupakan pengakuan bahwa kejahatan korupsi yang selama ini ada dalam kehidupan bermasyarakat, berbangsa dan bernegara telah mencapai taraf tersistematisir dengan berbagai pola, menyeluruh dan sulit ditanggulangi. ${ }^{2}$

Korupsi di Indonesia sudah menjadi fenomena yang sangat mencemaskan, karena telah semakin meluas dan merambah pada lembaga eksekutif, legislatif dan yudikatif. Kondisi tersebut telah menjadi salah satu faktor penghambat utama pelaksanaan pembangunan di Indonesia. Ketidakberhasilan pemerintah memberantas korupsi juga semakin melemahkan citra pemerintah dimata masyarakat dalam pelaksanaan pemerintahan yang tercermin dalam bentuk ketidakpercayaan masyarakat, ketidakpatuhan masyarakat terhadap hukum, dan vertambahnya jumlah angka kemiskinan absolut. Apabila tidak ada perbaikan yang berarti, maka kondisi tersebut akan sangat membahayakan kesatuan dan persatuan bangsa.

Bambang Widjojanto, "Harmonisasi Peran Penegak Hukum Dalam Pemberantasan Korupsi", Jurnal Legislasi Indonesia Vol. 4 No. 1 Maret 2007, Jakarta Selatan: Ditj en Peraturan Perundang-undangan. hlm. 1
Frekuensi dan sampai seberapa jauh korupsi yang terjadi di Indonesia menurut catatan statistik, baik yang diajukan ke pengadilan dan yang tercatat pada kejaksaan (dalam proses pemeriksaan) akan tetap dalam tingkatan konstan, sementara tingkat pengetahuan masyarakat mengenai kejahatan serupa berbeda dari waktu ke waktu, atau dengan perkataan lain, pengetahuan masyarakat tentang korupsi mengalami keterbatasan, sehingga kelihatannya tingkat korupsi stabil, sedangkan hakekatnya meningkat. ${ }^{3}$ Data Indonesia Corruption Watch (ICW) mengungkapkan, hingga kini sudah ada 16 kementerian yang telah terjerat kasus korupsi. Kementerian ini ada yang masih dalam dugaan kasus korupsi maupun sudah ada putusan pengadilan yang tetap. Sebagian besar (kementerian) di Era pemerintahan SBY, sebagian sebelum KPK dibentuk. ${ }^{4}$

Di era reformasi tuntutan pelaksanaan kepemerintahan yang baik (good governance) semakin kuat dijalankan sehingga ditetapkanlah TAP MPR RI No. XI/MPR/ 1999 tentang Penyelenggaraan Negara yang bersih dan bebas Korupsi, Kolusi dan Nepotisme (KKN) dan diperkuat lagi dengan UU No. 2 Tahun 1999 tentang Penyelenggaraan Negara yang bersih dan bebas KKN. Pemerintah semakin menegaskan tekad untuk sentiasa bersungguh-sungguh mewujudkan penyelenggaraan pemerintahan yang didasarkan pada prinsip-prinsip good governance dan pemberantasan korupsi.

Fadillah Putra secara provokatif memastikan bahwa seluruh belahan dunia sekarang tak berani berbeda pendapat ketika konsep good governance dikatakan sebagai solusi berbagai persoalan kehidupan di dunia ini. Mu-lai dari pengaturan pemerintahan di tingkat nasional hingga pedesaan, konsep good governance menj adi solusi. Bahkan sekolah, BUMN, perbankan, dunia bisnis, Ketua RT, warung hingga

\footnotetext{
3 Sri Sumawarni, "Korupsi Sebagai Tindak Pidana Dalam UU No. 3 Tahun 1971 dan UU No. 20 Tahun 2001 Tentang Pemberantasan Tindak Pidana Korupsi", J urnal Hukum Khaira Ummah Vol. III, No. 2, September 2008, Semarang: Fakultas Hukum UNISSULA. hIm. 226

4 M. Purwadi, "Peran KY dalam Pengawasan Hakim Tipikor: Memberikan "Perhatian" Pada Pengadilan Tipikor", Buletin Komisi Yudisial, Vol. VI No. 1, Agustus 2011, J akarta: Komisi Yudisial. hlm. 11
} 
penjual nasi goreng sekarang telah menyepakati bahwa mereka harus menerapkan good governance theory dalam praktek keseharian mereka. $^{5}$

Penyelenggaraan pemerintahan yang baik (Good Governance) adalah pemerintahan yang memberikan berbagai kemudahan, kepastian dan bersih dalam menyediakan pelayanan dan perlindungan dari berbagai tindakan sewenangwenang baik atas diri, hak ataupun harta bendanya. Oleh karena itu sangat wajar apabila tuntutan penyusunan kebijakan pemerintah yang bersih dalam kerangka rencana aksi daerah pemberantasan korupsi terutama ditujukan pada pembaharuan administrasi negara dan juga penegak hukum.

Menurut Menurut Abdul Gani Abdullah, good governance itu berhubungan erat dengan manajemen pengelolaan kebijakan pembangunan (khususnya bidang hukum). Apabila seorang pejabat publik akan mengambil keputusan dalam melaksanakan pembangunan, terlebih dahulu dia harus menerapkan prinsip-prinsip penyelenggaraan pemerintahan yang baik sehingga hasil akhirnya secara menyeluruh adalah suatu perintah yang baik. Keputusan yang diambil oleh seroang pejabat publik baik itu berbentuk kebijakan (beschiking) maupun aturan umum (regeling) harus benar-benar berdasarkan kewenangan yang diberikan undang-undang maupun yang dilimpahkan oleh pejabat. Ciri good governance di sini adalah keputusan tersebut diambil secara demokratis, transparan, akuntabilitas, dan benar. ${ }^{6}$ Good governance adalah prinsip yang mengetengahkan keseimbangan hubungan antara masyarakat dengan negara serta negara dengan pribadi. Dengan demikian setiap kebijakan publik seharusnya melibatkan berbagai sektor baik masyarakat maupun sektor privat dengan code of conduct nya yang jelas. ${ }^{7}$

\footnotetext{
Fadillah Putra, "Perangkap Good Governance dalam Liberalisasi Konstitusi Indonesia", J urnal Konstitusi Vol. 4 No. 2, J uni 2007.J akarta: Mahkamah Konstitusi.

6 Abdul Gani Abdullah, "Legal Drafting dan Good Governance", Jurnal Keadilan Vol. 5. No. 2 2002, J akarta: Pusat Kajian Hukum Dan Keadilan.

Teten Masduki, "Implementasi Prinsip Good Governance di Indonesia", Jurnal Keadilan Vol. 5. No. 2 2002, J akarta: Pusat Kajian Hukum Dan Keadilan.
}

Pertimbangan lahirnya Rancangan Undang Undang (RUU) Administrasi Pemerintahan setidaknya menunjukan upaya pemerintah untuk memberikan kepastian hukum atas setiap tindakan yang dilakukan pemerintah dan upaya untuk menciptakan perlindungan hukum kepada warga masyarakat secara adil dan tidak berpihak guna mewujudkan penyelenggaraan administrasi pemerintahan yang transparan, mudah, cepat, tepat, pasti, efisien, efektif dan partisipatif. Hal inilah yang menjadi sebab mengapa Good Governance berhadapan secara kasat mata dengan tindak pidana korupsi yang berlaku di birokrasi. ${ }^{8}$

Banyaknya peraturan perundang-undangan mengenai korupsi yang dibuat sejak tahun 1957, sebenarnya memperlihatkan besarnya niat bangsa Indonesia untuk memberantas korupsi hingga saat ini, baik dari sisi hukum pidana material maupun hukum pidana formal (hukum acara pidana). Walaupun demikian, masih didapati kelemahan yang dapat disalahgunakan oleh tersangka untuk melepaskan diri dari jeratan hukum.

Terlepas dari kuantitas peraturan perundang-undangan yang dihasilkan, dalam pelaksanaannya, instrumen normatif ternyata belum cukup untuk memberantas korupsi. Permasalahan utama pemberantasan korupsi juga berhubungan dengan sikap dan perilaku. Struktur dan sistem politik yang korup telah melahirkan apatisme dan sikap yang cenderung toleran terhadap perilaku korupsi. Akibatnya sistem sosial yang terbentuk dalam masyarakat telah melahirkan sikap dan perilaku yang permisif dan menganggap korupsi sebagai suatu hal yang wajar dan normal. Sebagai contoh di bidang pelayanan publik, biaya ekstra atau pungutan liar meru-pakan gambaran sehari-hari yang umum terli-hat pada kantor-kantor pelayanan masyarakat. Masyarakat dapat melihat dengan kasat mata dan merasakan praktik korupsi yang semakin marak dan meluas. Laporan pengaduan pun banyak mengalir dari masyarakat, selain

\footnotetext{
Dwiyanto Indiahono, "Korupsi Versus Good Governance: Analitis Kritis Pemberdayaan Pers Melawan Korupsi", J urnal IImu Hukum Ammana Gappa, Vol. 17 No. 1, Maret 2009, Makassar: Fakultas Hukum UNHAS. hlm. 33
} 
itu, korupsi juga banyak terjadi pada kegiatankegiatan pemerintah yang berhubungan dengan penerimaan dan pembelanj aan uang negara.

Korupsi selain terkait dengan aturan normatif yang lemah, sikap dan perilaku juga disebabkan karena lemahnya sistem manajemen sumber daya manusia dari penyelenggara pemerintahan, mulai dari sistem rekruitmen, karir dan promosi serta penilaian kinerja sampai kepada remunerasinya. Cukup banyak contoh birokrasi nepotisme dalam sistem rekruitmen, karir dan promosi pegawai negeri sipil yang merupakan bibit-bibit korupsi yang berkembang dalam setiap lini pemerintahan sampai dengan saat ini.

Penanganan korupsi selama ini menghadapi berbagai hambatan serius yang dikelompokkan menjadi empat. ${ }^{9}$ Pertama, hambatan struktural, yaitu hambatan yang bersumber dari praktek-praktek penyelenggaraan negara dan pemerintahan yang membuat penanganan tindak pidana korupsi tidak berjalan sebagaimana mestinya. Termasuk dalam kelompok ini diantaranya meliputi egoisme sektoral dan institusional yang menjurus pada pengajuan dana sebanyak-banyaknya untuk sektor dan instansinya tanpa memperhatikan kebutuhan nasional secara keseluruhan serta berupaya menutup-nutupi penyimpangan-penyimpangan yang terdapat di sektor dan instansi yang bersangkutan, belum berfungsinya fungsi pengawasan secara efektif, lemahnya koordinasi antara aparat pengawasan dan aparat penegak hukum, serta lemahnya sistem pengendalian intern. Kedua, hambatan kultural, yaitu hambatan yang bersumber dari kebiasaan negatif yang berkembang di masyarakat. Termasuk dalam kelompok ini diantaranya meliputi: masih adanya sikap sungkan dan toleran diantara aparatur pemerintah yang dapat menghambat penanganan tindak pidana korupsi, kurang terbukanya pimpinan instansi sehingga sering terkesan toleran dan melindungi pelaku korupsi, campur tangan eksekutif, legislatif dan yudikatif dalam penanganan tindak pidana

9 Agung Djoyosoekarto, Diani sadiawati, Hera Setiawati, 2008, Membangun Sistem Integritas dalam Pemberantasan Korupsi di Daerah, J akarta: Kemitraan, hlm. 51 korupsi, rendahnya komitmen untuk menangani korupsi secara tegas dan tuntas, serta sikap masa bodoh sebagian besar masyarakat terhadap upaya pemberantasan korupsi. Ketiga, hambatan instrumental, yaitu yang bersumber dari kurangnya instrumen pendukung dalam bentuk peraturan perundang-undangan yang membuat penanganan tindak pidana korupsi tidak berjalan sebagaimana mestinya. Keempat, hambatan manajemen, yaitu hambatan yang bersumber dari diabaikannya atau tidak diterapkannya prinsip-prinsip manajemen yang baik yang membuat penanganan tindak pidana korupsi tidak berjalan sebagaimana mestinya.

Selain hambatan tersebut di atas, dalam penanganan pemberantasan korupsi yang masih menjadi masalah adalah masih lemahnya sistem pengawasan terhadap lembaga penegak hukum. Masyarakat telah semakin skeptis dan curiga dengan pengawasan internal yang dilakukan oleh masing-masing lembaga penegak hukum, bahkan seringkali dituduh sebagai tempat melindungi aparat yang bersalah. Walaupun pengawasan eksternal saat ini telah semakin intensif dilakukan oleh masyarakat, namun masih menjadi kendala berupa keterbatasan masyarakat untuk memperoleh akses informasi terhadap proses penanganan perkara korupsi maupun putusan terhadap perkara korupsi. Hal ini menjadi tuntutan utama, khususnya dari kelompok masyarakat yang menaruh perhatian pada masalah korupsi.

Instruksi Presiden Nomor 5 Tahun 2004 tentang Percepatan Pemberantasan Tindak Pidana Korupsi, menginstruksikan kepada para Gubernur serta para Bupati dan Walikota dalam rangka percepatan pemberantasan korupsi, untuk meningkatkan kualitas pelayanan kepada publik baik dalam bentuk jasa ataupun perizinan melalui transparansi dan standar pelayanan minimum yang meliputi persyaratanpersyaratan, kemudahan/kesederhanaan dan kepastian target waktu penyelesaian, serta tarif biaya yang harus dibayar oleh masyarakat untuk mendapatkan pelayanan tersebut sesuai peraturan perundang-undangan dan menghapuskan pungutan-pungutan liar. 
Berkaitan dengan peningkatan kualitas pelayanan publik sebagai upaya percepatan pemberantasan korupsi, Instruksi Presiden No. 5 Tahun 2004 diarahkan pada beberapa bidang. Bidang pencegahan tindak pidana korupsi dengan kegiatan meliputi: pertama, penyempurnaan sistem pelayanan publik dengan hasil yang diharapkan adalah kejelasan dan kemudahan pelayanan kepada masyarakat dalam waktu, biaya dan persyaratan; kedua, pengelolaan laporan harta kekayaan penyelenggaraan Negara dengan hasil yang diharapkan peningkatan jumlah Pejabat/ Pejabat Negara Wajib Lapor; dan ketiga, peningkatan efektifitas pengawasan penyelenggaraan pemerintahan daerah, pembinaan aparatur dan penanganan pengaduan masyarakat dengan hasil yang diharapkan adalah perbaikan kinerja perangkat daerah. Bidang penindakan tindak pidana korupsi melalui kegiatan dukungan terhadap upaya-upaya penindakan tindak pidana korupsi dengan hasil yang diharapkan adalah peningkatan kelancaran penanganan kasus oleh Aparat Penegak Hukum serta jumlah Peraturan Daerah yang direvisi. Bidang monitoring dan evaluasi melalui kegiatan monitoring, evaluasi dan pelaporan dengan hasil yang diharapkan antara lain peningkatan kepercayaan masyarakat terhadap kesungguhan dan komitmen Pemerintah Daerah dalam memberantas korupsi serta memperjelas langkah-langkah Pemerintah Daerah terhadap komitmen pemberantasan korupsi, di mana pada dua cabang pemerintahan inilah yang berhubungan dengan masyarakat dalam hal pelayanan dan perlindungan.

\section{Permasalahan}

Berdasarkan latar belakang tersebut, maka dapat diketengahkan perumusan masalah yaitu: Bagaimanakah implementasi pemerintahan yang bersih dalam kerangka Rencana Aksi Daerah Pemberantasan Korupsi (RAD-PK) di Kabupaten Pemalang?

\section{Metode Penelitian}

Kegiatan penelitian ini dilakukan dalam upaya untuk menganalisis pelaksanaan kebijakan pemerintahan Kabupaten Pemalang dalam mewujudkan pemerintahan yang bersih dalam kerangka rencana aksi daerah pemberantasan korupsi (RAD-PK). Sehubungan dengan itu, metode penelitian yang dipilih yaitu metode deskriptif dengan pendekatan kualitatif. Dalam pendekatan kualitatif, data yang dikumpulkan umumya berbentuk kata-kata, gambar dan bukan angka-angka, kalaupun ada angka-angka sifatnya hanya sebagai penunjang. Data dimaksud meliputi transkrip wawancara, catatan dan lapangan, foto-foto, dokumen pribadi, nota, dan catatan lain-lain. Atas alasan itulah dipilihnya pendekatan kualitatif-deskriptif.

\section{Pembahasan}

Salah satu program good governance adalah pemberantasan korupsi, kolusi dan nepotisme. Korupsi menurut Klitgoard ditimbulkan karena ada monopoli, kekuasaan, dan diskresi yang begitu besar. Selama masih ada sentralisasi kekuasaan dan aturan-aturan yang tidak jelas dan tidak ada pertanggungjawaban publik maka akan menimbulkan peluang korupsi. ${ }^{10} \mathrm{Di}$ Indonesia dapat lihat peluang korupsi begitu besar, birokrasi begitu panjang, gaji pegawai negeri yang kecil, tidak adanya sistem public complain dan hampir semua partai politik mencari uang untuk membesarkan partainya.

Seiring dalam upaya pencegahan dan pemberantasan korupsi, kolusi dan nepotisme (KKN), serta mewujudkan peran masyarakat untuk mencegah dan memberantasnya, maka pemerintah Indonesia telah mengeluarkan berbagai peraturan perundang-undangan, antara lain UU No. 3/ 1971 tentang Pemberantasan Tindak Pidana Korupsi; UU No. 11/1980 tentang Pemberantasan Tindak Pidana Suap; UU No. 28/ 1999 tentang Penyelenggaraan Negara Yang Bersih dan Bebas dari Korupsi, Kolusi dan Nepotisme; UU No. 31/ 1999 tentang Pemberantasan Tindak Pidana Korupsi; UU No. 20/ 2001 tentang Perubahan atas UU No. 31/1999 tentang Pemberantasan Tindak Pidana Korupsi; UU No. 30/ 2002 tentang Komisi Pemberantasan Tindak Pidana Korupsi; PP No. 30/1980 tentang Disiplin

10 Robert Kligoard, 2005, Penuntun Pemberantasan Korupsi dalam Pemerintahan Daerah, Jakarta: Yayasan Obor Indonesia, hlm. 3. 
Pegawai Negeri sipil; PP No. 71/2000 tentang Tata Cara Pelaksanaan Peran Serta Masyarakat dan Pemberian Penghargaan Dalam Pencegah dan Pemberantasan Tindak Pidana Korupsi. Instruksi Presiden No. 5 / 2004 tentang Percepatan Pemberantasan Korupsi.

Pemberantasan korupsi sebagai salah satu prioritas dalam kebijakan nasional dan komitmen untuk secara berkesinambungan mewujudkan tata pemerintahan yang baik dan bebas dari korupsi, kolusi dan nepotisme. Upaya pemberantasan korupsi secara represif selama ini dianggap masih lamban Instruksi Presiden No. 5 Tahun 2004 tentang Percepatan Pemberantasan Korupsi tersebut secara umum menginstruksikan kepada seluruh jajaran pemerintah dan secara khusus pada instansi tertentu, untuk melaksanakan tugas-tugas tertentu dalam rangka mempercepat upaya pemberantasan korupsi.

Pada tingkat daerah didorong untuk menyusun Rencana Aksi Daerah Pemberantasan Korupsi (RAD-PK) yang merupakan suatu dokumen yang menjadi pedoman penyearah implementasi komitmen pemerintah daerah dalam menanggulangi korupsi. Program aksi ini berisikan langkah-langkah konkrit yang telah disepakati para pemangku kepentingan di daerah dalam rangka percepatan pemberantasan korupsi. Pada prinsipnya program aksi ini menunjuk pada komitmen pemerintah daerah dalam melakukan upaya pencegahan terjadinya korupsi melalui pengembangan program dan kegiatan yang bertujuan untuk perbaikan pelayanan publik, penataan sistem keuangan serta perbaikan sistem administrasi pemerintahan daerah.

Pelaksanaan Rencana Aksi Daerah Dalam Pemberantasan Korupsi (RAD-PK) merupakan tindak lanjut dan amanat dari Instruksi Presiden No. 5 Tahun 2004 tentang Percepatan Pemberantasan Korupsi menjadi suatu keharusan dalam rangka membangun kerangka sistem dalam pencegahan korupsi, sehingga dalam pelaksanaannya diperlukan tindakan represif, maka pengenaan tindakan hukum harus tetap dilakukan. Untuk itu komitmen dari aparat yang berwenang bersama dengan elemen masyarakat merupakan faktor penting agar RAD-PK berjalan sesuai dengan harapan.

Implementasi RAD-PK di Kabupaten Pemalang dalam kurun waktu 2007-2011 diarahkan pada tiga bidang. Bidang Pencegahan Tindak Pidana Korupsi, dengan kegiatan antara lain: pertama penyempurnaan sistem pelayanan publik dengan hasil yang diharapkan adalah kejelasan dan kemudahan pelayanan kepada masyarakat dalam waktu, biaya dan persyaratan; kedua, pengelolaan laporan harta kekayaan penyelenggaraan negara dengan hasil yang diharapkan adalah peningkatan jumlah pejabat negara wajib lapor; dan ketiga, peningkatan efektivitas pengawasan penyelenggaraan pemerintahan daerah, pembinaan aparatur, dan penanganan pengaduan masyarakat dengan hasil yang diharapkan adalah perbaikan kinerja perangkat daerah.

Langkah-langkah pencegahan tindak pidana korupsi di Kabupaten Pemalang disesuaikan dengan diktum yang ada pada Kementrian PAN yaitu: pertama, Penetapan Pejabat/ Penyelenggara Negara yang Wajib LHKPN di lingkungan Pemerintah Kabupaten Pemalang; kedua, Penetapan kinerja; ketiga, Peningkatan Kualitas Pelayanan Publik; keempat, Penetapan Program dan Wilayah Bebas Korupsi; kelima, Pelaksanaan Kepres No. 80 Tahun 2003; keenam, Penetapan Kesederhanaan Hidup; ketujuh, Dukungan terhadap Aparat Penegak Hukum terhadap Upaya Penindakan Korupsi; kedelapan, peningkatan pengawasan dan pembinaan aparatur; kesembilan, penerapan prinsip-prinsip tata kepemerintahan yang baik di lingkungan Pemerintah Daerah Kabupaten Pemalang; dan kesepuluh, peningkatan pelayanan publik dan meniadakan pungutan liar dalam pelaksanaannya.

Bidang Penindakan Tindak Pidana Korupsi, menyelenggarakan kegiatan terhadap upayaupaya penindakan tindak pidana korupsi dengan hasil yang diharapkan adalah peningkatan kelancaran penanganan kasus oleh aparat penegak hukum serta jumlah Perda yang direvisi. Kegiatan dari penindakan tindak pidana korupsi meliputi penerbitan izin pemeriksaan oleh aparat penegak hukum, pengawasan represif terha- 
dap produk hukum Pemerintah Kabupaten Pemalang.

Bidang Monitoring dan Evaluasi melalui kegiatan monitoring, evaluasi dan pelaporan dengan hasil yang diharapkan antara lain peningkatan kepercayaan masyarakat terhadap kesungguhan dan komitmen Pemerintah Daerah dalam memberantas korupsi serta memperjelas langkah-langkah Pemerintah Daerah terhadap komitmen pemberantasan korupsi.

Kabupaten Pemalang sejak tahun 2007 telah memiliki RAD-PK yang dituangkan dalam Peraturan Bupati Pemalang No. 67 Tahun 2007 yang merupakan payung hukum dalam upaya pencegahan KKN selama 2007-2011. RAD-PK tersebut selama ini telah diimplementasikan secara partisipatif. Selama kurun waktu 2007 2011 sebenarnya pemerintah Kabupaten Pemalang telah mengimplementasikan beberapa langkah kebijakan yang sinergis dengan upaya pemberantasan korupsi di Kabupaten Pemalang dengan langkah-langkah sebagai berikut. Pertama, penerbitan Instruksi Bupati Nomor 6 Tahun 2007 tentang Pemakaian Lencana Bendera Merah Putih. Kebijakan ini mulanya diterapkan bagi aparatur pemerintah daerah yang dimaksudkan sebagai upaya menerjemahkan dan menumbuhkan jiwa patriotisme sehingga diharapkan selalu tertanam kesadaran peran aparatur sebagai pelayanan masyarakat. Seiring dengan berjalannya waktu respon masyarakat terhadap penerapan kebijakan tersebut meluas hingga kalangan pelajar, hal tersebut sebagai upaya dini penerapan jiwa patriotisme dan menjaga konsistensi upaya penyelenggaraan kehidupan yang bebas korupsi, kolusi dan nepotisme. Kedua, penerbitan Surat Edaran Bupati Pemalang Nomor 3186/426/ Org tentang Himbauan Penggunaan Alat Transportasi Sepeda. Kebijakan ini diterapkan khususnya bagi aparatur yang secara geografi memungkinkan untuk dilaksanakan misalnya jarak yang tidak terlalu jauh (radius $5 \mathrm{~km}$ ). Hal ini juga sebagai upaya contoh kepada masyarakat bahwa penyelenggaraan kesederhanaan hidup dapat ditempuh juga dalam pelaksanaan tugas keseharian. Ketiga, penerbitan Keputusan Bupati Pemalang Nomor. 050/01.C/2008 tentang Pem- bentukan Unit Pelayanan Pengadaan Barang/ Jasa Pemerintah Kabupaten Pemalang Tahun 2008. Kebijakan ini relevan dalam rangka tertib administrasi pengadaan barang/jasa sehingga terwujud transparasi dan akuntabilitas dalam penyelenggaraannya.

Selain beberapa langkah tersebut di atas, pemerintah Kabupaten Pemalang juga menerapkan kebijakan yang sifatnya lebih implementatif. Wujud kebijakan yang lebih implementatif ini antara lain: pertama, pencanangan area bebas pungutan liar, sebagai wujud tekad pemerintah daerah khususnya pada institusi pelayanan seperti Unit Pelayanan Perizinan dan Investasi. Kegiatan ini berupa pemasangan papan himbauan dan spanduk untuk mengingatkan tekad memberantas korupsi. Kedua, pemberian balas jasa (reward) dan hukuman (punishment) bagi aparat yang melaksanakan tugas keseharian. Kegiatan ini dilaksanakan pada saat apel pagi minggu pertama setiap bulan berdasarkan laporan dan absensi yang dilakukan oleh SKPD kepada Badan Kepegawaian Daerah (BKD). Hal ini dilakukan sebagai bentuk perhatian pimpinan sehingga bawahan merasa mendapatkan perlakuan yang adil atas segala tindakan yang dilakukannya. Ketiga, penandatangan Pakta Integritas bagi penyelenggara pemerintahan daerah mulai dari perangkat desa, kecamatan, sampai Satuan Kerja Perangkat Daerah (SKPD) di tingkat kabupaten sampai pejabat negara seperti bupati dan wakil bupati. Kegiatan ini diharapkan sebagai benteng moral untuk tidak melakukan penyimpangan bagi segenap aparatur dalam setiap tindakan yang dilakukan selama melaksanakan tugas.

Berbagai kebijakan diatas memang terimplementasi secara partisipatif oleh segenap SKPD, namun demikian kegiatan yang ada masih sebatas pada tindakan seremonial. Oleh karena itu untuk kedepannya diperlukan suatu implementasi RAD-PK yang mampu meningkatkan komitmen dan mampu membangun strategi baru dalam percepatan pemberantasan korupsi. Intinya RAD-PK bukan hanya sebuah dokumen semata yang berisi berbagai program atau kegiatan tapi RAD-PK yang ada bisa menjadi ruh yang 
menjiwai bagi semua pemangku kepentingan di Kabupaten Pemalang dalam bertindak.

Gambaran mengenai implementasi RADPK Kabupaten Pemalang dalam kurun waktu 2007-2011 berdasarkan hasil penelitian yang dilakukan pada berbagai SKPD secara umum da- pat diinventariskan berbagai program yang dijalankan dan permasalahan yang dihadapi. Secara umum implementasi RAD-PK Kabupaten Pemalang dan hambatan yang ditemui dapat dilihat pada tabel berikut:

Tabel 1 Gambaran Umum Implementasi RAD-PK 2007-2011 kabupaten Pemalang dan Hambatannya

\begin{tabular}{|c|c|}
\hline KEGIATAN/PROGRAM & HAMBATAN \\
\hline Bidang Pencegahan Tindak Pidana Korupsi & \multirow{6}{*}{$\begin{array}{l}\text { Secara umum hambatan dan permasalahan } \\
\text { yang ditemui dalam implementasi RAD - PK } \\
\text { Kabupaten Pemalang 2007-2011 adalah : } \\
\text { - Kurangnya sosialisasi RAD-PK pada aparatur } \\
\text { pemerintah dimana sosialisasi sebatas pada } \\
\text { pejabat eselon semata hal ini menjadikan } \\
\text { RAD-PK hanya sebuah dokumen program/ } \\
\text { kegiatan semata belum menjadi jiwa bagi } \\
\text { aparatur pemerintah dalam memberantas } \\
\text { korupsi. } \\
\text { - Program/ kegiatan yang ada beberapa ma- } \\
\text { sih merupakan kegiatan seremonial } \\
\text { - Belum semua SKPD memiliki persepsi dan } \\
\text { pemahaman yang sama tentang pelaksa- } \\
\text { naan kebijakan pemerintahan yang bersih } \\
\text { dalam kerangka rencana aksi daerah pem- } \\
\text { berantasan korupsi (RAD-PK) } \\
\text { - Sistem pelayanan publik yang belum sepe- } \\
\text { nuhnya pro publik } \\
\text { - Penerapan Prinsip-prinsip good governance } \\
\text { yang belum optimal } \\
\text { - Masih lemahnya pengawasan terhadap lem- } \\
\text { baga penegak hukum } \\
\text { - Belum terbentuknya Tim Monev RAD - PK }\end{array}$} \\
\hline $\begin{array}{l}\text { 1. Program Penyempurnaan Sistem Pelayanan Publik } \\
\text { - Fasilitasi pelayanan masyarakat melalui penyelengga- } \\
\text { raan pelayanan satu pintu (one stop service) } \\
\text { - Peningkatan pelayanan air bersih } \\
\text { - Fasilitasi pelayanan perizinan pertanahan } \\
\text { 2. Program Kesederhanaan Hidup } \\
\text { - Penghematan pemakaian listrik di setiap SKPD } \\
\text { - Penghematan pemaikaian telepon di setiap SKPD } \\
\text { - Penghematan pemaikaian BBM di setiap SKPD } \\
\text { 3. Program Peningkatan Pengawasan dan Pembinaan Apara- } \\
\text { tur } \\
\text { - Pemeriksaan Kasus pengaduan masyarakat atas dugaan } \\
\text { korupsi } \\
\text { - Rakor pengendalian operasional dan kegiatan (Dalop- } \\
\text { tan) khususnya pengadaan barang dan jasa } \\
\text { 4. Program Penerapan Prinsip-prinsip tata kepemerintahan } \\
\text { yang baik } \\
\text { - Transparansi, partisipasi dan akuntabilitas tata kepe- } \\
\text { merintahan di lingkungan Pemda }\end{array}$ & \\
\hline Bidang Penindakan Tindak Pidana Korupsi & \\
\hline $\begin{array}{l}\text { Program Dukungan Terhadap Lembaga Penegak Hukum } \\
\text { - Mendukung penegakan hukum dalam penindakan pelaku } \\
\text { tipikor } \\
\text { - Meningkatkan koordinasi dan persamaan persepsi antar } \\
\text { lembaga internal dan eksternal dengan lembaga penegak } \\
\text { hukum }\end{array}$ & \\
\hline Bidang Monitoring dan Evaluasi Tindak Pidan & \\
\hline $\begin{array}{l}\text { 1. Pembentukan tim monitoring } \\
\text { 2. Pengumpulan informasi tentang proses hukum } \\
\text { 3. Mengadakan Survey } \\
\text { 4. Mengadakan Pemantauan terhadap pelaksanaan RAD-PK } \\
\text { yang menyangkut perbaikan peraturan }\end{array}$ & \\
\hline
\end{tabular}

Berdasarkan tabel diatas, dapat dikatakan bahwa selama ini Rencana Aksi Daerah Kabupaten Pemalang 2007-2011 telah diimplementasikan secara partisipatif oleh aparatur pemerintah di lingkungan Pemda Kabupaten Pemalang. Maksudnya adalah bahwa program dan kegiatan yang ada dalam RAD-PK dalam kesempatan tertentu sudah dijalankan oleh aparatur pemerintah meskipun sifatnya tidak kontinyu tapi sebatas pada acara-acara seremonial semata. Misalnya untuk penggunaan lencana merah putih, penggunaan hanya pada buIan Agustus dalam rangka hari kemerdekaan. Kondisi tersebut memberikan suatu asumsi bah- 
wa RAD-PK masih sebatas sebuah dokumen yang berisi berbagai program atau kegiatan yang bersifat seremonial.

Sosialisasi mengenai RAD-PK hanya bersifat parsial pada pejabat Pemda Pemalang sehingga banyak aparat Pemda tidak mengeta-hui apa sebenarnya subtansi dari adanya RAD-PK sehingga tidak merasa perlu untuk menjadi-kan diktum-diktum yang ada didalamnya sebagai panduan dalam berkarya dalam keseharian. Maka yang terjadi adalah RAD-PK hanyalah sebuah dokumen semata sama seperti dokumen lainnya yang hanya ada sebagai formalitas bahwa dokumen itu memang harus ada sebagai suatu ketentuan. Hal inilah yang menjadikan belum semua SKPD memiliki persepsi dan pemahaman yang sama tentang pelaksanaan kebijakan pemerintahan yang bersih dalam kerangka rencana aksi daerah pemberantasan korupsi (RAD-PK)

Adanya rasa apatis dari aparatur tentang pelaksanaan RAD-PK telah menjadikan kegiatan yang ada sebagai suatu rutinitas yang hanya dilaksanakan sebagi sebuah formalitas. Kondisi ini telah membuat penjaminan akan program dan kegiatan RAD-PK seolah terabaikan karena belum adanya monitoring dan evaluasi. Ke depan untuk memperbaiki kinerja dari berbagai program dan kegiatan yang ada dalam RAD-PK perlu dibentuk suatu tim monitoring dan evaluasi RAD-PK. Hal ini penting karena dengan adanya tim monitoring dan evaluasi ini diharapkan kegiatan dalam RAD-PK menjadi lebih terpantau. Selain membentuk tim monitoring dan evaluasi diperlukan pula suatu cara yang $\mathrm{j} i$ tu untuk mensosialisasikan apa itu RAD-PK kepada seluruh aparat pemerintah daerah. Salah satu cara yang bisa ditempuh adalah melalui safari RAD-PK bagi semua aparat di semua SKPD. Safari ini juga bisa digunakan sebagai jaring aspirasi aparat tiap SKPD untuk memberikan masukan, saran dan kritik terhadap RAD-PK yang ada. Dari forum seperti inilah biasanya ide-ide segar dan kreatif yang mengusung aspirasi budaya dan kearifan lokal muncul yang selanjutnya bisa kita jadikan sebagai suatu kegiatan unggulan yang mencirikan sekaligus membedakan Kabupaten Pemalang dengan ka- bupaten lainnya sehingga menjadi sebuah keunggulan komparatif.

Suatu kearifan lokal atau sering disebut local wisdom dapat dipahami sebagai usaha manusia dengan menggunakan akal budinya (kognisi) untuk bertindak dan bersikap terhadap sesuatu, objek, atau peristiwa yang terjadi dalam ruang tertentu. Pengertian di atas, disusun secara etimologi, di mana wisdom dipahami sebagai kemampuan seseorang dalam menggunakan akal pikirannya dalam bertindak atau bersikap sebagai hasil penilaian terhadap sesuatu, objek, atau peristiwa yang terjadi. Sebagai sebuah istilah wisdom sering diartikan sebagai 'kearifan/kebijaksanaan'. kearifan Iokal dapat ditemui dalam nyayian, pepatah, sasanti, petuah, semboyan, dan kitab-kitab kuno yang melekat dalam perilaku sehari-hari. Kearifan lokal biasanya tercermin dalam kebiasaan-kebiasaan hidup masyarakat yang telah berlangsung lama. Keberlangsungan kearifan lokal akan tercermin dalam nilai-nilai yang berlaku dalam kelompok masyarakat tertentu. Nilainilai itu menjadi pegangan kelompok masyarakat tertentu yang biasanya dapat diamati melalui sikap dan perilaku mereka sehari-hari yang tidak terpisahkan. Kemunculan kearifan lokal dalam masyarakat merupakan hasil dari proses trial and error dari berbagai macam pengetahuan empiris maupun non empiris atau yang estetik maupun intuitif. Kearifan lokal lebih menggambarkan satu fenomena spesifik yang biasanya akan menjadi ciri khas komunitas kelompok tersebut

Sebagi contoh, bahwa saat ini di Pemda Kabupaten Pemalang untuk tiap waktu tertentu secara rutin diadakan kegiatan istighosah. Kegiatan ini merupakan cerminan perilaku masyarakat Pemalang yang agamis sebagai salah satu kota yang dapat dikatakan sebagai kota santri. Kegiatan istighosah ini dapat menjadi suatu kegiatan pendidikan karakter aparat dalam usaha pencegahan korupsi. Selain itu kegiatan istighosah yang selama ini ada juga bisa jadikan kegiatan bagi para birokrat Pemda dalam rangka pendidikan karakter yang mencerminkan pemalang sebagai salah satu kota santri sesuai dengan visi Pemalang yaitu "Ka- 
bupaten Pemalang yang Sehat, Cerdas, Berdaya Saing dan Berakhlak Mulia".

Kabupaten Pemalang berkomitmen dan mendukung penuh terhadap kebijakan pemerintah dalam upaya pemberantasan korupsi. Dukungan Kabupaten Pemalang terhadap upaya percepatan pemberantasan korupsi lebih lanjut dituangkan dalam Rencana Aksi Daerah Percepatan Pemberantasan Korupsi (RAD-PK) Tahun 2012-2016 yang mengacu pada Rencana Pembangunan J angka Menengah (RPJ M) Daerah Kabupaten Pemalang 2011 - 2016 dan Rencana Aksi Nasional Pemberantasan Korupsi (RAN-PK) dan Instruksi Presiden No. 5 Tahun 2004 tentang Percepatan Pemberantasan Korupsi, yang menginstruksikan kepada para Gubernur, Bupati dan Walikota dalam rangka percepatan pemberantasan korupsi melalui peningkatan kualitas pelayanan publik.

Instruksi Presiden No. 5 Tahun 2004 masih sesuai dengan tujuan keempat RPJMD Kabupaten Pemalang 2011-2016 yaitu meningkatkan tata kelola pemerintahan daerah yang baik, melalui pelayanan prima sesuai dengan prinsip-prinsip good governance. Selanjutnya sasaran Peningkatan Kapasitas Pemerintahan Daerah Guna Perwujudan Kepemerintahan yang Baik dan Pelayanan Prima Kabupaten Pemalang adalah: tersusunnya orientasi target capaian standar pelayanan minimum pelayanan dasar, meningkatnya kualitas pengawasan dan status audit keuangan daerah, meningkatnya penanganan kasus korupsi, kolusi dan nepotisme, meningkatnya kualitas pelayanan administrasi kependudukan melalui sistem informasi administrasi kependudukan, meningkatkan kapasitas pemerintah daerah, penguatan aspek-aspek perencana daerah, aspek kelembagaan, kepegawaian dan aset daerah.

Strategi untuk mencapai meningkatkan tata kelola pemerintahan daerah yang baik, melalui pelayanan prima sesuai dengan prinsip-prinsip good governance yaitu: pertama, meningkatkan kapasitas dan profesionalisme aparatur pemerintah daerah melalui pendidikan lanjut, diklat dan bintek bagi segenap aparatur pemerintah. Kedua, meningkatkan prasa- rana dan sarana pelayanan publik di setiap SK$P D$, kecamatan dan pemerintah desa/ kelurahan agar kinerja pelayanan publik lebih baik. Ketiga, meningkatkan transparansi dan akuntabilitas penyelenggaraan pemerintahan dan pembangunan melalui pengembangan monitoring, evaluasi dan pelaporan keuangan. Keempat, menegakkan hukum terhadap praktik Korupsi, Kolusi dan Nepotisme dan penyalahgunaan wewenang. Kelima, meningkatkan pelayanan administrasi kependudukan dan pencatatan sipil melalui pelayanan dengan teknologi informasi (TI) dan peningkatan kesadaran masyarakat.

Dalam rangka mewujudkan pemerintahan yang bersih dalam kerangka rencana aksi daerah pemberantasan korupsi Kabupaten Pemalang tetap memprioritaskan pada upaya peningkatan kualitas pelayanan publik sebagai upaya percepatan pemberantasan korupsi. Oleh karena itu RAD-PK Kabupaten Pemalang Tahun 2012-2016 masih diprioritaskan pada dua bidang yaitu bidang pencegahan tindak pidana korupsi dan bidang monitoring dan evaluasi. Pada bidang pencegahan tindak pidana korupsi, kegiatan yang dilakukan antara lain: pertama, penyempurnaan sistem pelayanan publik dengan hasil yang diharapkan adalah kejelasan dan kemudahan pelayanan kepada masyarakat dalam waktu, biaya dan persyaratan di semua pelayanan publik; kedua, pengelolaan laporan harta kekayaan penyelenggaraan negara dengan hasil yang diharapkan adalah peningkatan jumlah Pejabat Negara Waj ib Lapor dan sebagai sarana pengawasan terjadinya tipikor; ketiga, peningkatan ef ektivitas pengawasan penyelenggaraan pemerintahan daerah, pembinaan aparatur, dan penanganan pengaduan masyarakat dengan hasil yang diharapkan adalah perbaikan kinerja perangkat daerah.

Langkah- langkah Pencegahan dalam RADPK di Kabupaten Pemalang masih disesuaikan dengan diktum yang ada pada Kementrian PAN yaitu: penetapan pejabat/ penyelenggara negara yang wajib LHKPN di lingkungan Pemerintah Kabupaten Pemalang; penetapan kinerja; peningkatan kualitas pelayanan publik; penetapan program dan wilayah bebas korupsi; pelaksa- 
naan Kepres No. 80 Tahun 2003 jo Perpres 54 Tahun 2010; penetapan kesederhanaan hidup; dukungan terhadap aparat penegak hukum terhadap Upaya penindakan korupsi; peningkatan pe-ngawasan dan pembinaan aparatur; penerapan prinsip-prinsip tata kepemerintahan yang baik di lingkungan Pemerintah Daerah Kabupaten Pemalang; peningkatan pelayanan publik dan meniadakan pungutan liar dalam pelaksanaannya/ LPL.

Bidang Penindakan Tindak Pidana Korupsi Melalui kegiatan terhadap upaya-upaya penindakan tindak pidana korupsi dengan hasil yang diharapkan adalah peningkatan kelan-caran penanganan kasus oleh aparat penegak hukum serta jumlah Perda yang direvisi. Kegiatan dari penindakan tindak pidana korupsi meliputi: penerbitan izin pemeriksaan oleh aparat penegak hukum dan pengawasan represif terhadap produk hukum Pemerintah Kabupaten Pemalang.

Bidang Monitoring dan Evaluasi melalui kegiatan monitoring, evaluasi dan pelaporan dengan hasil yang diharapkan antara lain peningkatan kepercayaan masyarakat terhadap kesungguhan dan komitmen Pemerintah Daerah dalam memberantas korupsi serta memperjelas langkah-langkah Pemerintah Daerah terhadap komitmen pemberantasan korupsi.

RAD-PK meskipun menggunakan istilah "pemberantasan" namun kegiatannya lebih difokuskan pada aspek pencegahan terutama yag terkait dengan kualitas pelayanan publik. Oleh karena itu secara administratif RAD-PK adalah sebuah dokumen yang memuat program aksi yang bertujuan untuk mempercepat pemberantasan korupsi. RAD-PK sebagai suatu program aksi memuat langkah-langkah konkrit yang telah disepakati para pemangku kepentingan di daerah, sehingga telah menjadi komitmen pemerintah daerah dalam melakukan upaya pencegahan terjadinya korupsi melalui pengembangan program dan kegiatan yang bertujuan untuk perbaikan pelayanan publik serta penerapan prinsip-prinsip tata kepemerintahan yang baik. Berikut ini adalah program dan kegiatan dalam RAD-PK 2012-2016 Kabupaten Pemalang.
Tabel 2 Program dan Kegiatan RAD-PK Kabupaten Pemalang Tahun 2012-2016 Bidang Pencegahan Tindak Pidana Korupsi

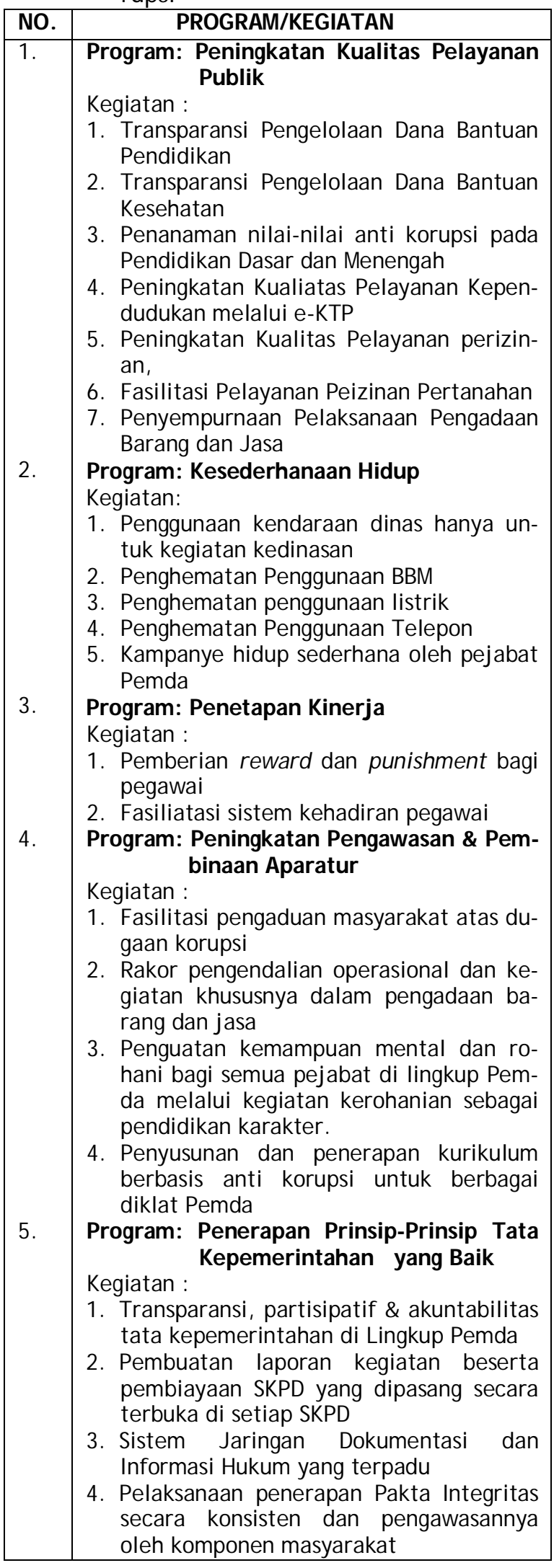


Peningkatan kualitas pelayanan publik masih menjadi prioritas dalam bidang pencegahan korupsi dalam RAD-PK 2012-2016 Kabupaten Pemalang. Peningkatan kualitas pelayanan publik masih relevan dengan amanat dalam Instruksi Presiden No. 5/ 2004 dimana pada diktum ke empat diamanatkan kepada berbagai instansi baik pusat ataupun daerah untuk meningkatkan kualitas pelayanan kepada publik baik dalam bentuk jasa ataupun perijinan melalui transparansi dan standarisasi pelayanan yang meliputi persyaratan-persyaratan, target waktu penyelesaian, dan tarif biaya yang harus dibayar oleh masyarakat untuk mendapatkan pelayanan tersebut sesuai peraturan perundang-undangan dan menghapuskan pungutan-pungutan liar.

Berbicara mengenai pelayanan publik mau tidak mau harus berurusan dengan yang namanya birokrasi. Birokrasi dalam posisi ini lebih sebagai suatu organisasi yang besar dengan pola sentralistik yang memiliki posisi, wewenang dan kekuasaan yang sangat kuat dalam memobilisasi sumber daya pembangunan, perencanaan maupun pelaksanaan pemerintahan. Padahal Salah satu faktor rendahnya pemberian pelayanan yang berkuaitas adalah rendahnya sumberdaya manusia. ${ }^{11}$ Pada dasarnya peranan birokrasi adalah sebagai pelayan publik (public servant), sehingga dapat dikatakan sebagai ujung tombak pelayanan publik karena di ranah inilah terjadi interaksi langsung antara pemberi pelayanan dengan masyarakat sebagai penerima layanan.

Pelayanan publik dapat diartikan sebagai suatu pelayanan umum yang dilaksanakan oleh pemerintah dalam rangka memenuhi kebutuhan masyarakat. Dalam kapasitasnya sebagai public servant maka tugas utama dari pemerintah adalah memberikan pelayanan bagi masyarakatnya sesuai dengan tuntutan akan situasi dan kondisi perubahan perkembangan yang

11 Dwiyanto Indiahono, "Gagasan Reformasi Birokrasi dalam Rancangan Undang Undang (RUU) Tentang Administrasi Pemerintahan", J urnal Dinamika Hukum Vol. 11 No. 1, J anuari 2011, Purwokerto: Fakultas Hukum UNSOED. hlm. 176 terus terjadi. Kondisi saat ini menuntut suatu pelayanan yang lebih baik, sederhana, cepat dan murah.

Pelayanan yang cepat, tepat, akurat, murah dan ramah, serta sederhana bagi masyarakat Indonesia masih sebatas harapan. Selama ini pelayanan yang diperoleh masyarakat berkaitan dengan pelayanan publik masih jauh dari harapan, karena pelayanan yang diperoleh adalah lamban, berbelit-belit, mahal dan rawan terjadinya korupsi. Kondisi ini tentunya menuntut untuk diadakannya perubahan pada lembaga-lembaga pelayanan publik agar mereka dapat memberikan pelayanan yang lebih baik bagi masyarakat. Oleh karena itu Program dan Kegiatan RAD-PK Kabupaten Pemalang Tahun 2012-2016 Bidang Pencegahan Tindak Pidana Korupsi diuraikan pada bagian di bawah ini.

\section{Peningkatan Kualitas Pelayanan Publik.}

Seperti yang diamanatkan dalam Instruksi Presiden No. 5 Tahun 2004 tentang Percepatan Pemberantasan Korupsi, yang menginstruksikan kepada para Gubernur, Bupati dan Walikota dalam rangka percepatan pemberantasan korupsi melalui peningkatan kualitas pelayanan publik dengan meningkatkan kualitas pelayanan kepada publik dalam bentuk jasa atau pun perijinan melalui transparansi dan standarisasi pelayanan yang meliputi persyaratan-persyaratan, target waktu penyelesaian, dan tarif biaya yang harus dibayar oleh masyarakat untuk mendapatkan pelayanan tersebut sesuai peraturan perundang-undangan dan menghapuskan pungutan-pungutan liar. Instruksi Presiden No. 5 Tahun 2004 bertujuan untuk mencegah terjadinya penyimpangan dalam bentuk kolusi, korupsi dan nepotisme

Kegiatan yang ada dalam rangka meningkatkan kualitas pelayanan publik adalah sebagai berikut. Pertama, peningkatan kualitas pelayanan perizinan, melalui penyelenggaraan One Stop Service Plus di bidang perizinan. Maksud dari kegiatan ini adalah melalui penyelenggaraan OSS Plus di bidang perizinan dilakukan melalui peningkatan sarana prasarana yang memadai untuk kegiatannya misal mela- 
lui Sistem Layanan Informasi Manajemen, yaitu suatu sistem dimana untuk formulir persyaratan bisa diunduh melalui internet. Selanjutnya juga perlu adanya tinjau ulang peraturan-peraturan yang menghambat OSS seta menyusun peraturan yang dapat menunjang pelaksanaan OSS seperti adanya aturan mengenai kemudahan ataupun pemberian keringanan biaya dalam perizinan tertentu. Inovasi tersebut tersebut akan memberi nilai lebih OSS Pemalang dengan daerah lainnya dan juga menjadi keunggulan komparatif.

Program ini ada kesamaan dengan yang dilaksanakan di beberapa Daerah, seperti Kabupaten Purbalingga. Pelayanan perizinan dan investasi pada awalnya kewenangannya berada pada berbagai dinas teknis untuk selanjutnya digabung dan dijadikan dalam satu lembaga baru yaitu Kantor Pelayanan Perizinan dan Investasi (KPPI) sebagai skala prioritas untuk menekan seminimal mungkin biaya ekonomi tinggi yang membebani masyarakat pengguna jasa kantor-kantor yang berhubungan dengan pelayanan perizinan dengan jalan menata ulang pelayanan perizinan melalui mekanisme One Stop Service (OSS) serta melakukan deregulasi dengan mengkaji dan merevisi Perda-Perda perizinan yang tidak sesuai lagi dengan tuntutan kondisi global. Sasaran dibentuknya KPPI adalah terciptanya pelayanan dengan prosedur yang lebih sederhana, cepat, akurat dan transparan. ${ }^{12}$

Luaran yang diharapkan dari adanya OSS Plus adalah terwujudnya peraturan yang mendukung OSS, hasil yang diharapkan adalah meningkatnya jumlah berbagai perijinan. Peningkatan berbagai perizinan akan tercapai jika di dukung oleh sarana prasarana yang memadai (gedung, penataan ruang, sistem layanan dll) dan sosialisasi yang menyeluruh disetiap kecamatan sebagai tempat pendelegasian dalam pengelolaan sebagian perizinan. Fasilitasi peningkatan pelayanan kesehatan masyarakat, melalui transparansi pengelolaan dana bantu-

12 Hikmah Nuraini, "One Stop Service Alternatif Model Pelayanan Pubik yang Terintegrasi", J urnal Visi Publik Vol. 4 No. 2 April 2008. Puwokerto: J urusan Adminitrasi Negara FISIP UNSOED. an kesehatan. Kegiatan ini dapat dilakukan dengan mengadakan program KIS (Koordinasi, Integrasi dan Sinkronisasi) berbagai programprogram kesehatan masyarakat yang telah ada selama ini. Luaran dari kegiatan ini adalah terbentuknya KIS sistem pelayanan kesehatan masyarakat, serta sosialisasi program-program kesehatan masyarakat. Selain itu juga diharapkan akan munculnya trans-paransi dalam pengelolaan bantuan kesehatan. Hasilnya adalah meluasnya informasi tentang program kesehatan masyarakat dan cara mendapat dan menggunakannya.

Kedua, peningkatan kualitas pelayanan Kependudukan melalui e-KTP. Kegiatan ini merupakan program yang tengah diterapkan di Pemalang dalam rangka menertibkan data kependudukan berbasis internet. Luaran adanya sistem kependudukan (KTP) yang terintegrasi. Hasilnya adalah adanya data kependudukan yang valid dengan satu identitas yang multi fungsi.

Ketiga, fasilitasi pelayanan peizinan pertanahan. Kegiatan ini masih merupakan kegiatan yang perlu dilakukan dimana mahalnya biaya pengurusan sertifikat menjadi kendala, sehingga banyak masyarakat yang belum mensertifikatkan tanahnya. Kegiatannya adalah sosialisasi program-program pertanahan seperti Program Larasita oleh Tim yang telah di bentuk. Hasilnya adalah meningkatnya transparans dalam persyaratan sertifikat. Keempat, penyempurnaan pelaksanaan pengadaan barang dan jasa. Kegiatan pelaksanaan pengadaan barang dan jasa telah diatur dengan jelas di Keppres No. 80 tahun 2003 dengan beberapa perubahannya dan terakhir dengan Perpres No. 54 Tahun 2010 tentang Pengadaan Barang/J asa Pemerintah, dimana untuk kegiatannya adalah melalui informasi pengadaan barang dan jasa melalui media massa

Hasil yang diharapkan adalah adanya transparansi dalam pengadaan barang dan jasa. Perbaikan Sistem Palayanan Pendidikan. Tempat pendidikan adalah suatu tempat dimana kita belajar akan pengetahuan, yang akan kita gunakan sebagai bekal menghadapi masa depan. Akan sangat potensial dalam rangka 
menciptakan generasi masa depan yang penuh kejujuran sehingga korupsi dapat dicegah secara dini maka adanya kurikulum berbasis anti korupsi sebagai muatan lokal akan sangat membantu dalam penciptaan generasi anti korupsi. Untuk itu diperlukan suatu sistem pelayanan pendidikan yang pro masyarakat dan bisa dijangkau oleh semua lapisan masyarakat. Apalagi untuk saat ini berbagai dana bantuan pendidikan sangat melimpah. Agar dana yang ada bisa bermanfaat bagi semua lapisan masyarakat perlu adanya pengawasan dalam pengelolaannya, salah satunya adalah dengan transparansi pengelolaan bantuan operasional sekolah.

Untuk kegiatan e-KTP, fasilitasi pelayanan perizinan pertanahan, dan pelayan kesehatan akan lebih efektif jika untuk sosialisasinya dapat dilakukan secara terintegrasi seperti melalui perkumpulan PKK atau Dasa Wisma dengan melibatkan berbagai staf terkait bidang masing-masing. Dimana pada pertemuan seperti inilah sosialisasi akan berjalan efektif dan mengena sampai pelosok.

\section{Kesederhanaan Hidup}

Kegiatan yang ada pada program kesederhanaan hidup adalah sebagai berikut. Pertama, penggunaan kendaraan dinas hanya untuk kegiatan kedinasan. Penggunaan mobil dinas selayaknya memang untuk kedinasan, namun yang sering terjadi adalah kendaraan dinas sering digunakan untuk kepentingan pribadi/keluarga. Luaran yang ingin dicapai adalah adanya efektifitas penggunaan mobil dinas yang kaitannya adalah dengan efektifnya pengeluaran BBM mobil dinas dan juga memunculkan perilaku pejabat untuk bijaksana dalam penggunaan mobil dinas. Kedua, penghematan penggunaan BBM, listrik, air, telepon. Kegiatan ini adalah untuk mengefisienkan pengeluar-an untuk pemakaian listrik, BBM, Telpon dan air pada instansi pemerintah sehingga hasil yang dicapai adalah adanya efesiensi belanja untuk keempat barang tersebut. Ketiga, kampanye hidup sederhana dan bersahaja oleh pejabat Pemerintah Daerah. Kegiatan ini diharapkan dilakukan oleh pejabat
Pemda dengan misal tidak membawa pulang mobil dinas, selalu menyambangi stafnya. Tujuannya adalah agar mereka memberikan contoh bagi stafnya tentang kesederhanaan dan perilaku yang ber-sahaja dengan memberikan perhatian walau pun itu cuma senyum dan sapa.

\section{Penetapan Kinerja}

Penetapan kinerja dilakukan melalui beberapa cara. Pertama, pemberian reward dan punishment bagi pegawai. Berupa kegiatan pemberian apresiasi bagi aparat yang berprestasi dengan model pemberian award yang pemberiannya diberikan langsung oleh bupati dan dimasukkan dalam media. Kondisi ini akan sangat meningkatkan mental aparat untuk bekerja dengan sepenuh hati karena ada perhatian dari atasan jadi penghargaan bukan semata dalam bentuk uang. Kedua, fasiliatasi sistem kehadiran pegawai. Kegiatan ini bisa dilakukan dengan sistem finger print bagi yang sudah memiliki fasilitasnya, bagi yang belum ada adalah adanya buku absensi dengan sistem penanda tanganan $4 \mathrm{x}$, pagi saat masuk, saat mau istirahat, habis istirahat dan jam pulang kerja.

\section{Peningkatan Pengawasan dan Pembinaan Aparatur}

Peningkatan pengawasan dan pembinaan aparatur dilakukan melalui beberapa langkah. Pertama, fasilitasi pengaduan masyarakat atas dugaan korupsi. Kegiatan ini lebih pada bagaimana penanganan atas pengaduan masyarakat atas dugaan korupsi, yang sebenarnya bisa dilakukan melalui SMS ataupun telepon center yang di sebarluaskan pada masyarakat, sehingga masyarakat mengetahui adanya tempat pengaduan atas dugaan korupsi. Kedua, rakor pengendalian operasional dan kegiatan khusus-nya dalam pengadaan barang dan jasa. Kegiat-an ini diharapkan dapat mengefisienkan pelaksanaan pengadaan barang dan jasa, sehingga monitoring dan evaluasinya menjadi lebih mudah

Ketiga, penguatan kemampuan mental dan rohani bagi semua pejabat di lingkup Pemda melalui kegiatan kerohanian sebagai pendi- 
dikan karakter. Kegiatan ini dapat dilakukan dengan kegiatan yang sudah ada misal kegiatan istighosah. Keempat, penyusunan dan penerapan kurikulum berbasis anti korupsi untuk berbagai diklat Pemda. Untuk berbagai diklat yang dilakukan pemda Pemalang diharapkan untuk selalui memasukan materi anti korupsi.

\section{Penerapan Prinsip-prinsip Tata Kepemerin- tahan yang Baik}

Penerapan prinsip ini dilakukan melalui transparansi, partisipatif dan akuntabilitas tata kepemerintahan di Lingkup Pemda. Kegiatan ini dilakukan dengan cara proses penyusunan, pelaksanaan dan dalam pertanggung-jawaban APBD; pembuatan laporan kegiatan beserta pembiayaan SKPD yang dipasang secara terbuka di setiap SKPD; sistem J aringan Dokumentasi dan Informasi Hukum yang terpadu; Pelaksanaan penerapan Pakta Integritas secara konsisten dan pengawasannya oleh komponen masyarakat.

Tabel 3 Program dan Kegiatan RAD-PK Kabupaten Pemalang Tahun 2012-2016 Bidang Penindakan Tindak Pidana Korupsi

\begin{tabular}{|l|l|}
\hline NO & \multicolumn{1}{|c|}{ PROGRAM/KEGIATAN } \\
\hline 1. & $\begin{array}{l}\text { Program: Dukungan terhadap Lembaga } \\
\text { Penegak Hukum }\end{array}$ \\
& $\begin{array}{l}\text { Kegiatan: } \\
\text { 1. Mendukung penegak hukum dalam pe- } \\
\text { nindakan tipikor }\end{array}$ \\
& $\begin{array}{l}\text { 2. Meningkatkan koordinasi dan persama- } \\
\text { an persepsi antar lembaga pemeriksa } \\
\text { internal dan eksternal dengan penegak } \\
\text { hukum }\end{array}$ \\
\hline
\end{tabular}

Kegiatan RAD-PK Pemalang 2012-1016 daIam Bidang Penindakan Tindak Pidana Korupsi dilakukan dengan dua cara. Pertama, mendukung penegak hukum dalam penindakan tipikor, kegiatan yang dilakukan dalam rangka mendukung penegak hukum dalam penindakan tindak pidana korupsi adalah dengan melakukan sosialisasi peraturan perundangundangan di bidang pemberantasan korupsi; mendukung setiap proses kegiatan yang berkaitan dengan penanganan tindak pidana korupsi. Hasil yang diharapkan adalah meningkatnya kepercayaan masyarakat terhadap aparatur pemerintah dan pe- negak hukum dalam upaya pemberantasan korupsi.

Kedua, meningkatkan koordinasi dan persamaan persepsi antar lembaga pemeriksa internal dan eksternal dengan penegak hukum. Kegiatan ini dilakukan dengan membentuk forum kerjasama antara pemda, kepolisian dan lembaga-lembaga terkait untuk meyesuaikan persepsi tentang cara-cara penindakan tindak pidana korupsi. Sehingga hasil yang di-peroleh adalah berjalannya tindak lanjut temuan hasil pemeriksaan tindak pidana korupsi secara hukum.

Tabel 4 Program dan Kegiatan RAD-PK Kabupaten Pemalang Tahun 20122016 Bidang Monitoring dan Evaluasi Tindak Pidana Korupsi

\begin{tabular}{|c|c|}
\hline NO & PROGRAM/KEGIATAN \\
\hline 1. & $\begin{array}{l}\text { Program : Monitoring dan Evaluasi } \\
\text { Kegiatan: } \\
\text { 1. Pembentukan tim Monev } \\
\text { 2. Pengumpulan informasi tentang proses } \\
\text { hukum tipikor } \\
\text { 3. Mengadakan survey tentang RAD-PK } \\
\text { 4. Mengadakan monev dalam implementasi } \\
\text { RAD-PK }\end{array}$ \\
\hline
\end{tabular}

Kegiatan dari program RAD-PK Kabupaten Pemalang 2012-2016 di bidang Monitoring dan Evaluasi adalah sebagai berikut. Pertama, pembentukan tim monev. Kegiatannya adalah membentuk suatu tim monitoring dan evaluasi dengan cara menyeleksi calon anggota dan menetapkannya. Tujuannya adalah terbentuknya Tim Monitoring dan Evaluasi. Kedua, pengumpulan informasi tentang proses hukum tipikor. Kegiatannya adalah tim monev melakukan pengumpulan informasi mengenai kasus tindak pidana korupsi dan proses penindakannya sampai pada taraf mana, sehingga akan diketahui berapa kasus tipikor yang ada dan sejauh mana penangannya. Ketiga, mengadakan survey tentang RAD-PK. Kegiatan ini untuk mengetahui seberapa efektif RAD-PK dengan upaya pemberantasan korupsi, apakah telah dapat menekan korupsi dengan berbagai program dan kegiatannya atau biasa saja. Keempat, mengadakan monev dalam implementasi RAD-PK. Kegiatan monitoring dan evaluasi RAD-PK dilakukan agar prog- 
ram dan kegiatannya apakah sudah sesuai atau belum, sehingga bisa dilakukan perbaikan.

\section{Penutup \\ Simpulan}

Beberapa simpulan dari pembhasan di atas sebagai berikut. Pertama, RAD-PK Kabupaten Pemalang 2007-2011 telah diimplementasikan secara partisipatif oleh aparatur pemerintah di lingkungan Pemda Kabupaten Pemalang. Kedua, RAD-PK masih sebatas sebuah dokumen yang berisi berbagai program atau kegiatan yang bersifat seremonial. Ketiga, sosialisasi mengenai RAD-PK hanya bersifat parsial pada pejabat Pemda Pemalang. Keempat, belum semua SKPD memiliki persepsi dan pemahaman yang sama tentang pelaksanaan kebijakan pemerintahan yang bersih dalam kerangka rencana RAD-PK. Kelima, belum adanya survey masyarakat mengenai persepsi implementasi RADPK. Keenam, belum optimalnya monitoring dan evaluasi terhadap implementasi RAD-PK.

\section{Saran}

Saran yang dapat diberikan adalah sebagai berikut. Pertama, hasil evaluasi implementasi RAD-PK selayaknya dibuka secara transparan kepada publik. Kedua, Perbaikan metodologi sosialisasi dan kampanye publik RAD-PK sangat diperlukan, agar rencana aksi ini menjadi kepentingan daerah dan diketahui semua pihak. Ketiga, perlu dibentuk suatu tim monitoring dan evaluasi. Keempat, mengadakan survey tentang implementasi RAD-PK di lingkup Pemda Pemalang. Kelima, mensinergikan upaya penyelenggaraan kebijakan pemerintahan yang bersih dalam kerangka rencana aksi daerah pemberantasan korupsi (RAD-PK) agar RAD-PK bukan hanya menjadi dokumen yang berisi program/kegiatan tapi mampu menjadi jiwa segenap aparat dalam upaya memberantas korupsi.

\section{Daftar Pustaka}

Abdullah, Abdul Gani. "Legal Drafting dan Good Governance". Jurnal Keadilan. Vol. 5 No.
2 tahun 2002. Jakarta: Pusat Kajian Hukum dan Keadilan;

Djoyosoekarto, Agung. Diani Sadiawati, Hera Setiawati. 2008. Membangun Sistem Integritas dalam Pemberantasa Korupsi di Daerah, Kemitraan. Jakarta;

Indiahono, Dwiyanto. "Gagasan Reformasi Birokrasi Dalam Rancangan Undang Undang (RUU) Tentang Administrasi Pemerintahan". Jurnal Dinamika Hukum. Vol. 11 No. 1. edisi Januari 2011. Purwokerto: Fakultas Hukum UNSOED;

"Korupsi Versus Good Governance: Analitis Kritis Pemberdayaan Pers Melawan Korupsi" Jurnal IImu Hukum Ammana Gappa. Vol. 17 No.1 edisi Maret 2009. Makassar: FH Universitas Hassanudin;

Kligoard, Robert. 2005. Penuntun Pemberantasan Korupsi dalam Pemerintahan Daerah. J akarta: Yayasan Obor Indonesia;

Manan, Bagir. 1999. Good Governance Hindarkan Rakyat dari Tindakan Negara yang Merugikan. Kompas, 15 November 1999;

Masduki, Teten. "Implementasi Prinsip Good Governance di Indonesia". J urnal Keadilan No. 2 Vol. 5 Tahun 2002. Jakarta: Pusat Kajian Hukum Dan Keadilan;

Nuraini, Hikmah. "One Stop Service Alternatif Model Pelayanan Pubik yang Terintegrasi". Jurnal Visi Publik. Vol. 4 No. 2 edisi April 2008. Purwokerto: J urusan IImu Administrasi Negara, FISIP UNSOED;

Purwadi, M. "Peran KY dalam Pengawasan Hakim Tipikor: Memberikan "Perhatian" Pada Pengadilan Tipikor". Buletin Komisi Yudisial. Vol. VI No. 1 edisi Agustus 2011. J akarta: Komisi Yudisial;

Putra, Fadillah. "Perangkap good governance dalam Liberalisasi Konstitusi Indonesia". J urnal Konstitusi. Vol. 4 No. 2 Edisi Juni 2007. J akarta: Mahkamah Konstitusi;

Sumawarni, Sri. "Korupsi Sebagai Tindak Pidana Dalam UU No. 3 Tahun 1971 dan UU No. 20 Tahun 2001". J urnal Hukum Khaira Ummah. Vol. III No. 2 edisi September 2008. Semarang: FH UNISSULA;

Widjojanto, Bambang. "Harmonisasi Peran Penegak Hukum dalam Pemberantasan Korupsi". J urnal Legislasi Indonesia. Vol. 4 No. 1 edisi Maret 2007. J akarta Selatan: Direktorat Jenderal Peraturan Perundang-undangan. 
Implementasi Pemerintahan yang Bersih dalam Kerangka Rencana Aksi Daerah... 2 